\title{
Pyoderma gangrenosum and cobalamin deficiency in systemic lupus erythematosus: a rare but non fortuitous association
}

\author{
Sing Chiek Teoh ${ }^{1}$, Chun Yang Sim² ${ }^{*} \mathbb{D}$, Seow Lin Chuah ${ }^{3}$, Victoria Kok and Cheng Lay Teh ${ }^{3}$
}

\begin{abstract}
Background: Pyoderma gangrenosum (PG) is an uncommon, idiopathic, ulcerative neutrophilic dermatosis. In many cases, PG is associated with a wide variety of different disorders but SLE in association with PG is relatively uncommon. In this article we present the case of a middle aged patient with PG as the initial clinical presentation of SLE. We also provide a brief review of cobalamin deficiency which occurred in our patient and evidence-based management options.
\end{abstract}

Case presentation: A 35 years old man presented with a 5 month history of debilitating painful lower limb and scrotal ulcers. This was associated with polyarthralgia and morning stiffness involving both hands. He also complained of swallowing difficulties. He had unintentional weight loss of $10 \mathrm{~kg}$ and fatigue. Physical examination revealed alopecia, multiple cervical lymphadenopathies, bilateral parotid gland enlargement and atrophic glossitis. There was Raynaud's phenomenon noted over both hands and generalised hyper-pigmented fragile skin. Laboratory results disclosed anaemia, leukopenia, hyponatraemia and hypocortisolism. Detailed anaemic workup revealed low serum ferritin and cobalamin level. The autoimmune screen showed positive ANA, anti SmD1, anti SSA/Ro 52, anti SSA/Ro 60, anti U1-snRNP with low complement levels. Upper gastrointestinal endoscopy with biopsies confirmed atrophic gastritis and duodenitis. Intrinsic factor antibodies and anti-tissue transglutaminase $\lg A$ were all negative. Punch biopsies of the leg ulcer showed neutrophilic dermatosis consistent with pyoderma gangrenosum. Based on the clinical findings and positive immunologic studies, he was diagnosed as systemic lupus erythematosus. His general condition improved substantially with commencement of corticosteroids, immunosuppressants and vitamin supplements.

Conclusions: We report a case of PG as the first manifestation of SLE which was treated successfully with immunosuppressants and vitamin supplements. Our report highlighted the need to consider connective tissue diseases such as SLE in a patient presenting with PG in order for appropriate treatment to be instituted thereby achieving a good outcome.

Keywords: Systemic lupus erythematosus (SLE), Pyoderma gangrenosum (PG), Cobalamin deficiency, Anaemia

\footnotetext{
* Correspondence: cysim@unimas.my

${ }^{2}$ Faculty of Medicine and Health Sciences, University Malaysia Sarawak, Jalan Datuk Mohammad Musa, 94300 Kota Samarahan, Sarawak, Malaysia

Full list of author information is available at the end of the article
}

(c) The Author(s). 2021 Open Access This article is licensed under a Creative Commons Attribution 4.0 International License, which permits use, sharing, adaptation, distribution and reproduction in any medium or format, as long as you give appropriate credit to the original author(s) and the source, provide a link to the Creative Commons licence, and indicate if changes were made. The images or other third party material in this article are included in the article's Creative Commons. licence, unless indicated otherwise in a credit line to the material. If material is not included in the article's Creative Commons licence and your intended use is not permitted by statutory regulation or exceeds the permitted use, you will need to obtain permission directly from the copyright holder. To view a copy of this licence, visit http://creativecommons.org/licenses/by/4.0/. The Creative Commons Public Domain Dedication waiver (http://creativecommons.org/publicdomain/zero/1.0/) applies to the data made available in this article, unless otherwise stated in a credit line to the data. 


\section{Background}

Pyoderma gangrenosum (PG) is a rare inflammatory and ulcerative disorder of the skin which is often associated with an underlying systemic disease in 50 to $70 \%$ of cases [1]. The underlying disease primarily include inflammatory bowel diseases, arthritides, IgA monoclonal gammopathies, and myeloid haematological malignancies. However, pyoderma gangrenosum may also occur on its own [1]. SLE and pyoderma gangrenosum is an uncommon association $[1,2]$. We found at least 25 cases of pyoderma gangrenosum associated with SLE in the literature [3]. The diagnosis of PG is made by excluding other causes of similarly appearing cutaneous ulcerations including infections, malignancies, vasculitides, vasculopathies, venous insufficiencies and trauma [1].

Anaemia is a common presentation in rheumatological diseases [4]. The prevalence of anaemia for patients with SLE was reported as $18-80 \%$ [5]. Anaemia of chronic disease (ACD) is the most common type $[6,7]$. Low cobalamin level was reported in certain SLE patients [8], however, pernicious anaemia is a rare association with SLE $[9,10]$.

We herein report an atypical case of SLE who presented with PG and cobalamin deficiency. We also discussed the possible pathophysiologic links and performed a literature review of previously published cases. The particularity of this case resides in its presentation and the dramatic improvement after treatment of the underlying aetiology.

\section{Case presentation}

A 35 years old man was hospitalised for multiple, painful and debilitating ulcers over both lower limb and scrotum. It initially started as a small wound over his right shin which gradually grew in size. Subsequently multiple similar lesions appeared extensively on both lower limb and scrotum over a period of 5 months. He was treated with multiple courses of antibiotics to no avail.

Additionally, he had 6 months history of polyarthralgia involving the inter-phalangeal joints of both hands, knees and elbows. He reported early morning stiffness of both hands with discolouration and numbness of his fingers upon exposure to cold temperatures. He also complained of bilateral lower limb numbness. He had significant impairment to his activities of daily living as a consequence of these symptoms. Besides that, he also complained of dysphagia, unintentional weight loss of $10 \mathrm{~kg}$ and fatigue.

There was no fever, recurrent oral ulcers, photosensitivity rash and history of gritty or red eyes. He denied chronic cough or night sweats. He had no abdominal pain or alteration in bowel habits. Review of other systems were unremarkable. Family and past medical history were insignificant. He denied alcohol intake, smoking, or use of recreational drugs. He was not a vegetarian and consumed meat regularly. There was no known food intolerance, medication allergies and surgical history.

On examination, the patient was afebrile and normotensive with a pulse rate of $110 \mathrm{bpm}$. There was clear evidence of alopecia, generalised hyper-pigmented fragile skin, depapillation of tongue and bilateral parotid swelling. Raynaud's phenomenon was noted over both hands. Multiple tiny lymph nodes were palpable over bilateral cervical and supraclavicular areas which were soft and mobile. There were multiple ulcers on his scrotum and both legs of varying ages indicating chronicity with the largest measuring $10 \times 5 \mathrm{~cm}$. The ulcers were irregular in shape, had erythematous-purplish borders with a yellowish necrotic base. However, the legs were warm and well perfused, with distinctly palpable peripheral pulses. There was no nodular lesions or thrombophlebitis over the lower extremities. Neurological examination of his lower limbs revealed symmetrical paraesthesia distally with loss of vibratory sensation and diminished proprioception. Respiratory, cardiovascular and abdominal examinations were normal (Fig. 1).

Laboratory investigations revealed haemoglobin of $8 \mathrm{~g} /$ $\mathrm{dl}$, mean corpuscular volume (MCV) of $84 \mathrm{fL}$, white blood cells of $6.27 \times 10^{\wedge} 3 / \mu \mathrm{L}$ with a lymphocyte count of

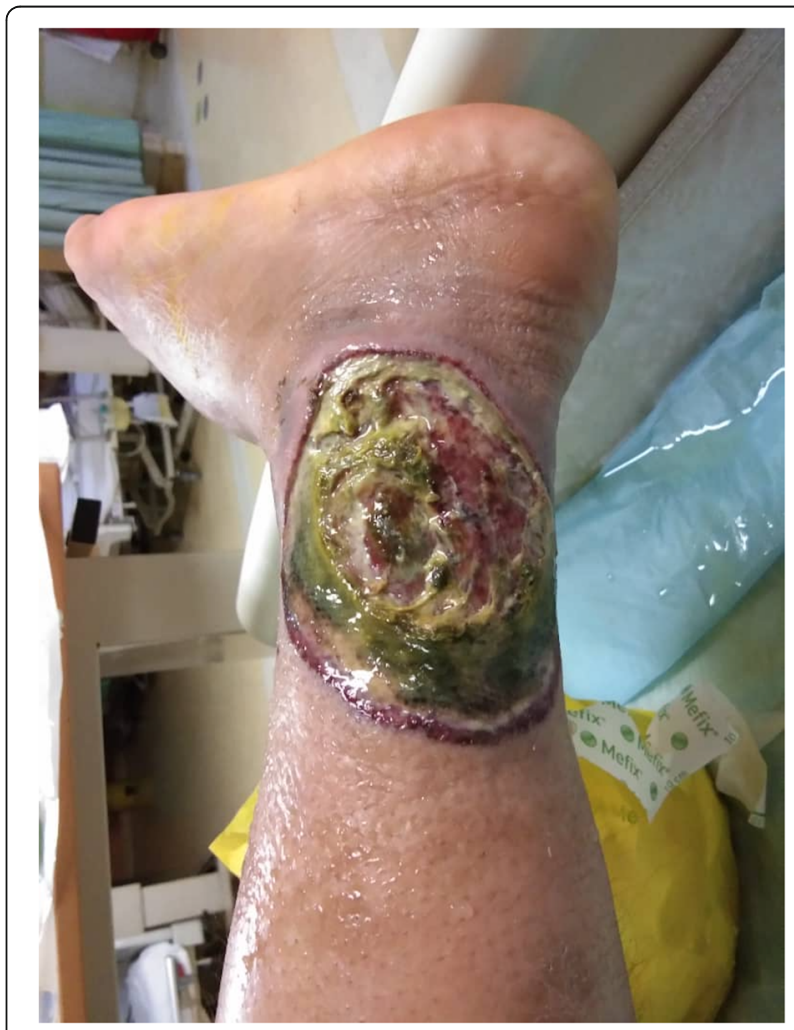

Fig. 1 Lesion over posterior aspect of right lower limb with necrotic base and red-blue border 
$1.02 \times 10^{\wedge} 3 / \mu \mathrm{L}$. A peripheral blood film showed normochromic, normocytic anaemia with no evidence of haemolysis or abnormal blast cells. Anaemic work up showed low serum iron of $3.7 \mu \mathrm{mol} / \mathrm{L}$, total iron binding capacity value of $25.3 \mu \mathrm{mol} / \mathrm{L}$, low transferrin saturation of $14.6 \%$, serum ferritin of $100 \mathrm{ng} / \mathrm{ml}$, low cobalamin level of 176 $\mathrm{pg} / \mathrm{mL}$ and normal folate level of $16.3 \mathrm{pg} / \mathrm{mL}$. Serum cortisol level was low at $124.6 \mathrm{nmol} / \mathrm{L}$ whilst sodium and potassium levels were also low at $130 \mathrm{mmol} / \mathrm{L}$ and 3.0 $\mathrm{mmol} / \mathrm{L}$ respectively. Liver function test showed low albumin level at $27 \mathrm{~g} / \mathrm{L}$ with slightly raised AST at $63 \mathrm{U} / \mathrm{L}$. Renal profile and coagulation screening were normal. Antinuclear antibody (ANA) was positive at a titre of 1 : 5120 which has a speckled pattern. Other autoimmune screening showed positive anti-SSA/Ro 60, anti-SSA/Ro 52, antiSmD1, and anti U1-snRNP. C-ANCA, p-ANCA, double stranded DNA, anti-SSB/La and rheumatoid factor were not detected. Complement 3 and 4 were below the reference range. Both inflammatory markers were elevated with CRP of $219 \mathrm{mg} / \mathrm{L}$ and ESR of $154 \mathrm{~mm} / \mathrm{hr}$. Serum protein electrophoresis displayed no paraprotein band or immunoparesis. Quantitative serum immunoglobulin test were normal. The serological tests for various infectious agents (HBsAg, anti $\mathrm{HCV}$ ab, anti HIV $1+2 \mathrm{ab}$ and treponemal tests) were negative. Intrinsic factor antibodies and anti-tissue transglutaminase IgA were below detection limits.

Cultures and sensitivities from the leg ulcers were positive for Proteus mirabilis. He was treated with a two-week course of intravenous amoxicillin/clavulanic acid. Histopathological examination of the leg ulcers demonstrated dense inflammatory cells infiltrate with neutrophil predominance. There was no evidence of necrotising vasculitis, vascular thrombosis, squamous dysplasia or invasive malignancy. No atypical mycobacteria or yeast were detected. An oesophagogastroduodenoscopy and colonoscopy was done which revealed atrophic gastritis, duodenitis and normal colonic mucosa. Campylobacter-like organism (CLO) test was negative. Histologically, the biopsies of small bowel showed well-formed and irregularly spaced glands secondary to expansion of lamina propria by lymphoplasmacytic inflammatory cell infiltrates. Colonic biopsies were insignificant. Periodic acid-Schiff (PAS) staining was negative. The findings were inconsistent with inflammatory bowel disease, Whipple's disease, coeliac disease or pernicious anaemia.

Based on clinical features, laboratory investigations, endoscopic and histological findings, he was diagnosed as SLE with pyoderma gangrenosum and cobalamin deficiency. He was treated with prednisolone, hydroxychloroquine, methotrexate, parenteral cyanocobalamin and iron supplements. Noticeable clinical improvement was observed after commencement of recommended treatment. Upon clinic review 1 month later, he reported weight gain, increased level of well-being, great improvement of skin lesions along with significant control of symptoms.

\section{Discussion and conclusion}

PG is part of the neutrophilic dermatosis spectrum of which immunohistological examination reveals neutrophilic predominant inflammatory reaction without evidence of infection [3]. The pathophysiology of PG is still unclear. An increasing body of evidence supports the role of pro-inflammatory cytokines like interleukin (IL)1-beta, IL-17 and tumour necrosis factor-alpha in the pathophysiology of neutrophilic dermatosis similar to classic monogenic auto-inflammatory diseases [3]. At present, there are no clear guidelines concerning PG treatment in patients with SLE [3].

The therapeutic strategy for neutrophilic dermatosis consists of modulating activation, maturation or migration of neutrophils with treatments such as colchicine, dapsone, corticosteroids and minocycline [3]. Interestingly, medications such as hydroxychloroquine, methotrexate, mycophenolate mofetil and cyclophosphamide used in modulating connective tissue diseases activity like SLE were reportedly effective on neutrophilic skin lesions as well [3]. This observation suggests that SLE and PG may share some common points in their pathogenesis [3].

From the literature search, there are at least 25 case studies of PG associated with SLE [3]. About 72\% (18/ 25 ) of these cases were diagnosed with SLE prior to the onset of PG, in comparison to $12 \%(3 / 25)$ who presented with PG prior to diagnosis of SLE [3]. Both diseases appeared simultaneously in $16 \%$ of the reported (4/25) cases [3]. Active lupus was seen in 12 patients at the time of PG onset, while 8 patients were asymptomatic of SLE [3]. However, in another 2 patients, the criteria of SLE were inconclusive [3]. In our patient, PG appeared simultaneously with active SLE. The occurrence of PG was correlated with the SLE activity in our patient as observed in the majority of the published cases of such association [3]. Main features of the 25 cases of PG associated with SLE and patients characteristics are tabulated in Table 1.

The prevalence of anaemia for patients with SLE was reported as $18-80 \%$ [5]. Anaemia in these patients consists of anaemia of chronic disease (ACD)(60-80\%), iron deficiency anaemia (IDA), autoimmune haemolytic anaemia (AIHA), and anaemia secondary to chronic renal insufficiency [6]. Other less common types of anaemia included pure red cell aplasia (PRCA), pernicious anaemia (PA), and aplastic anaemia [6]. In a study cohort consisting of 132 anaemic patients with SLE, ACD was found in $37.1 \%$ of the cases, IDA in $35 . \%$, AIHA in $14.4 \%$ and other causes of anaemia in $12.9 \%$ of the 
Table 1 Main characteristics of 26 SLE patients with pyoderma gangrenosum

\begin{tabular}{|c|c|c|c|c|c|}
\hline No. & Reference & $\begin{array}{l}\text { Gender/ } \\
\text { Age }\end{array}$ & $\begin{array}{l}\text { Location of lesion } \\
\text { (number) }\end{array}$ & $\begin{array}{l}\text { Timing of PG onset compared to SLE } \\
\text { diagnosis }\end{array}$ & $\begin{array}{l}\text { Lupus activity at the time of PG } \\
\text { onset }\end{array}$ \\
\hline 1. & Our patient & M/35 & Leg (MP) & Simultaneous & Signs of activity \\
\hline 2. & \multirow[t]{2}{*}{ Lebrun [3] } & $F / 32$ & Face (3) & 1 year later & No activity \\
\hline 3. & & $F / 37$ & Leg (MP) & 10 years later & Signs of activity \\
\hline 4. & \multirow{5}{*}{$\begin{array}{l}\text { Gonzalez-Moreno } \\
\text { [11] }\end{array}$} & M/46 & Leg (1) & After & Signs of activity \\
\hline 5. & & $F / 63$ & Foot (1) & After & No activity \\
\hline 6. & & $F / 42$ & Leg (1) & After & No activity \\
\hline 7. & & $F / 46$ & Leg (MP) & After & No activity \\
\hline 8. & & M/36 & Foot (MP) & After & Signs of activity \\
\hline 9. & Hamzi [12] & $F / 35$ & Leg (1) & 18 years later & No activity \\
\hline 10. & \multirow[t]{3}{*}{ Canas [13] } & NS/48 & MD & 2 years later & MD \\
\hline 11. & & NS/28 & MD & 4 years later & Signs of activity \\
\hline 12. & & NS/50 & MD & Simultaneous & MD \\
\hline 13. & $\begin{array}{l}\text { Husein-EIAhmed } \\
\text { [14] }\end{array}$ & M/36 & Foot (1) & 8 years later & No activity \\
\hline 14. & \multirow[t]{2}{*}{ Masatlioglu [15] } & $F / 35$ & Leg (1) & Simultaneous & Signs of activity \\
\hline 15. & & $F / 47$ & Thigh (1) & 10 months before & NA \\
\hline 16. & Hind [16] & F/14 month & Face, ends (MP) & Simultaneous & Signs of activity \\
\hline 17. & Reddy [17] & M/34 & Legs (MP) & After & Signs of activity \\
\hline 18. & Waldman [18] & $F / 35$ & Leg (MP) & 5 years before & NA \\
\hline 19. & Sakamoto [19] & $\mathrm{F} / 55$ & Trunk/chest/shoulders (MP) & 3 years later & Signs of activity \\
\hline 20. & Schmid [20] & $F / 64$ & Leg (2) & 11 years later & Signs of activity \\
\hline 21. & Holbrook [21] & $F / 57$ & Leg (1) & 2 years later & No activity \\
\hline 22. & Roger [22] & $F / 25$ & Foot (1) & 1 month later & Signs of activity \\
\hline 23. & Hostetler [23] & $F / 27$ & Trunk,chest, knees (MP) & 13 years later & No activity \\
\hline 24. & Pinto [24] & $F / 35$ & Leg (1) & 15 years later & Signs of activity \\
\hline 25. & Peterson [25] & $F / 48$ & $\begin{array}{l}\text { Intergluteal and inguinal } \\
\text { folds (6) }\end{array}$ & Simultaneous & Signs of activity \\
\hline 26. & Olson [26] & $F / 15$ & Leg (MP) & 1 year before & NA \\
\hline
\end{tabular}

$M$ male, $F$ female, $M P$ multiple, $M D$ missing data, $P G$ pyoderma gangrenosum, SLE systemic lupus erythematosus

patients [7]. Based on a study on 42 patients diagnosed with SLE, cobalamin levels were found to be significantly lower in the SLE group compared with a normal control group, eight of whom (18.6\%) had serum cobalamin levels equal to or lower than $180 \mathrm{pg} / \mathrm{mL}$ [8].

Our patient exhibited a mixed nutritional deficiency anaemia with both cobalamin and iron deficiencies. The possible mechanism for this may be explained by the presence of chronic atrophic gastritis seen endoscopically. Chronic atrophic gastritis results in the destruction of gastric mucosa parietal cells leading to reduced gastric acid secretion [27]. This precipitated the decrement in intrinsic factor production and food iron solubilisation, which eventually caused cobalamin and iron malabsorption [27]. The incidence of atrophic gastritis (AG) in SLE is low [28]. Immunological factors are known to be involved in the aetiology of the disease [28]. However, antiparietal cell antibodies and intrinsic factor antibodies are a rare finding [9]. Intrinsic factor antibodies were present in only $3 / 30(10 \%)$ SLE patients and $0 / 45$ controls in a study [10]. Pernicious anaemia (PA) is infrequently associated with SLE $[9,10]$. To the best of our knowledge, only four cases of PA was recorded among in patients with SLE [10]. This association of uncertain significance between SLE and PA suggested only a minority of cases of cobalamin deficiency in SLE would be related to the anti-intrinsic factor antibody [10]. Future investigations on the mechanisms of the cobalamin deficiency observed in SLE patients are required. This is an important recognition as low serum cobalamin concentrations is a precursor of PA.

The effective treatment for cobalamin deficiency are intramuscular (IM) injections of cyanocobalamin or oral therapy. Approximately $10 \%$ of the standard injectable 
dose of $1 \mathrm{mg}$ is absorbed, which allows for rapid replenishment in patients with severe deficiency or severe neurologic symptoms [29]. High-dose oral replacement ( $1 \mathrm{mg}$ to $2 \mathrm{mg}$ per day) was as effective as parenteral administration for correcting anaemia and neurologic symptoms [30]. However, there is a lack of data on the long-term benefit of oral therapy when patients do not take daily doses [30]. Therefore, intramuscular cobalamin was recommended for severe deficiency and malabsorption syndromes as in our patient. Oral replacement may be considered for patients with asymptomatic, mild disease with no absorption or compliance concerns [31].

A comprehensive and holistic approach in managing such patients is essential to get a confirmatory diagnosis. A multidisciplinary approach with various subspecialties e.g. rheumatologist, internists, gastroenterologists, dermatologists, etc. is utmost necessary to assist in the diagnosis of this patient. Diagnosis of PG and cobalamin deficiency should raise the possibility of concomitant autoimmune diseases, that could be missed if overlooked, resulting in significant delay in treatment which could be devastating. Overall, our case adds to the pool of knowledge about the pathogenesis, presentation and management of PG and cobalamin deficiency in association with SLE.

\section{Abbreviations}

SLE: Systemic Lupus Erythematosus; PG: Pyoderma gangrenosum; ANA: Antinuclear antibody; ANCA: Anti-neutrophil cytoplasmic antibody; pANCA: Perinuclear anti-neutrophil cytoplasmic antibodies; AST: Aspartate aminotransferase; CRP: C-reactive protein; ESR: Erythrocyte sedimentation rate

\section{Acknowledgements}

Not applicable.

\section{Authors' contributions}

TSC and SCY treated the patient and wrote the case report; CSL, VK and TCL supervised the writing and made some major changes in manuscript after reviewing the first versions. All authors read and approved the final manuscript.

\section{Funding}

Open Access funding provided by Universiti Malaysia Sarawak.

\section{Availability of data and materials}

Data are contained within the manuscript.

\section{Ethics approval and consent to participate}

All procedures were part of the standard medical care, and the need for ethics approval and consent to participate was waived.

\section{Consent for publication}

Written informed consent was obtained from the patient for publication of this case report and any accompanying images. A copy of the consent form is available for review by the Editor of this journal.

\section{Competing interests}

The authors declared that they have no competing interests.

\section{Author details}

'Department of Medicine, Sarawak General Hospital, Kuching, Sarawak, Malaysia. ${ }^{2}$ Faculty of Medicine and Health Sciences, University Malaysia Sarawak, Jalan Datuk Mohammad Musa, 94300 Kota Samarahan, Sarawak,
Malaysia. ${ }^{3}$ Department of Medicine, Rheumatology Unit, Sarawak General Hospital, Kuching, Sarawak, Malaysia.

Received: 7 October 2020 Accepted: 20 January 2021

Published online: 03 March 2021

\section{References}

1. Hau E, Vignon Pennamen MD, Battistella M, Saussine A, Bergis M, CavelierBalloy B, Janier M, Cordoliani F, Bagot M, Rybojad M, Bouaziz JD. Neutrophilic skin lesions in autoimmune connective tissue diseases: nine cases and a literature review. Medicine. 2014;93(29):e346. https://doi.org/10. 1097/MD.0000000000000346

2. Hania A. Pyoderma gangrenosum in a patient with systemic lupus erythematosus: case report. J Med Cases. 2014;5(8):455-8.

3. Lebrun D, Robbins A, Hentzien M, Toquet S, Plee J, Durlach A, Bouaziz JD, Bani-Sadr F, Servettaz A. Two case reports of pyoderma gangrenosum and systemic lupus erythematosus: a rare but nonfortuitous association? Medicine. 2018;97(34):e11933.

4. Segal R, Baumoehl Y, Elkayam O, et al. Anemia, serum vitamin B12, and folic acid in patients with rheumatoid arthritis, psoriatic arthritis, and systemic lupus erythematosus. Rheumatol Int. 2004;24(1):14-9. https://doi.org/10. 1007/s00296-003-0323-2.

5. Samohvalov E, Samohvalov S. The pattern of anemia in lupus, current topics in anemia, Jesmine Khan. IntechOpen. 2018. https://doi.org/10.5772/ intechopen.71293.

6. Bashal F. Hematological disorders in patients with systemic lupus erythematosus. Open Rheumatol J. 2013;7(1):87-95. https://doi.org/10.2174/ 1874312901307010087

7. Voulgarelis M, Kokori SI, loannidis JP, Tzioufas AG, Kyriaki D, Moutsopoulos HM. Anaemia in systemic lupus erythematosus: aetiological profile and the role of erythropoietin. Ann Rheum Dis. 2000;59(3):217-22. https://doi.org/10. 1136/ard.59.3.217

8. Molad Y, Rachmilewitz B, Sidi Y, Pinkhas J, Weinberger A. Serum cobalamin and transcobalamin levels in systemic lupus erythematosus. Am J Med. 1990, ISSN 0002-9343;88(2):141-4. https://doi.org/10.1016/00029343(90)90463-N.

9. Shih YL, Chang DM. Excellent effect of steroid plus azathioprine in a young woman with pernicious anaemia and systemic lupus erythematosus. Clin Rheumatol. 2000;19(6):492-4. https://doi.org/10.1007/s100670070015.

10. Schulz SW, Derk CT. The gastrointestinal manifestations of systemic lupus erythematosus: a survey of the literature. Open Autoimmunity J. 2009;1:1026. https://doi.org/10.2174/1876894600901010010.

11. Gonzalez-Moreno J, Ruiz-Ruigomez M, Callejas Rubio JL, et al. Pyoderma gangrenosum and systemic lupus erythematosus: a report of five cases and review of the literature. Lupus. 2015;24:130-7.

12. Hamzi AM, Bahadi A, Alayoud A, et al. Skin ulcerations in a lupus hemodialysis patient with hepatitis C infection: what is your diagnosis? Iran J Kidney Dis. 2013:7:191.

13. Canas CA, Duran CE, Bravo JC, et al. Leg ulcers in the antiphospholipid syndrome may be considered as a form of pyoderma gangrenosum and they respond favorably to treatment with immunosuppression and anticoagulation. Rheumatol Int. 2010;30:1253-7.

14. Husein-ElAhmed H, Callejas-Rubio JL, Rios Fernandez R, et al. Effectiveness of mycophenolic acid in refractory pyoderma gangreno sum. J Clin Rheumatol. 2010:16:346-7.

15. Masatlioglu SP, Goktay F, Mansur AT, et al. Systemic lupus erythematosus presenting as pyoderma gangrenosum in two cases. Rheumatol Int. 2009; 29:837-40.

16. Hind A, Abdulmonem AG, Al-Mayouf S. Extensive ulcerations due to pyoderma gangrenosum in a child with juvenile systemic lupus erythematosus and C1q defificiency. Ann Saudi Med. 2008;28:466-8.

17. Reddy V, Dziadzio M, Hamdulay S, et al. Lupus and leg ulcers - a diagnostic quandary. Clin Rheumatol. 2007:26:1173-5.

18. Waldman MA, Callen JP. Pyoderma gangrenosum Preceding the diagnosis of systemic lupus erythematosus. Dermatology. 2005;210:64-7.

19. Sakamoto T, Hashimoto T, Furukawa F. Pyoderma gangrenosum in a patient with bullous systemic lupus erythematosus. Eur J Dermatol. 2002;12:485-7.

20. Schmid MH, Hary C, Marstaller B, et al. Pyoderma gangrenosum associated with the secondary antiphospholipid syndrome. Eur J Dermatol. 1998;8:45-7.

21. Holbrook MR, Doherty M, Powell RJ. Post-traumatic leg ulcer. Ann Rheum Dis. 1996;55:214-5. 
22. Roger D, Aldigier JC, Peyronnet P, et al. Acquired ichthyosis and pyoderma gangrenosum in a patient with systemic lupus erythematosus. Clin Exp Dermatol. 1993;18:268-70.

23. Hostetler LW, von Feldt J, Werth VP. Cutaneous ulcers in a patient with systemic lupus erythematosus. Arthritis Rheum. 1993;36:91-3.

24. Pinto GM, Cabecas MA, Riscado M, et al. Pyoderma gangrenosum associated with systemic lupus erythematosus: response to pulse steroid therapy. J Am Acad Dermatol. 1991;24:818-21.

25. Peterson LL. Hydralazine-induced systemic lupus erythematosus pre senting as pyoderma gangrenosum-like ulcers. J Am Acad Dermatol. 1984;10:379-84.

26. Olson K. Pyoderma gangrenosum with systemic L.E. Acta Derm Venereol. 1971;51:233-4.

27. Rodriguez-Castro Kl, Franceschi M, Noto A, Miraglia C, Nouvenne A, Leandro G, Meschi T, De' Angelis GL, Di Mario F. Clinical manifestations of chronic atrophic gastritis. Acta Biomed. 2018;89(8-S):88-92. https://doi.org/10.23750/ abm.v89i8-S.7921.

28. Picceli VF, Skare TL, Nisihara R, Kotze L, Messias-Reason I, Utiyama SR. Spectrum of autoantibodies for gastrointestinal autoimmune diseases in systemic lupus erythematosus patients. Lupus. 2013;22(11):1150-5. https:// doi.org/10.1177/0961203313503911.

29. Stabler SP. Clinical practice. Vitamin B12 deficiency. N Engl J Med. 2013; 368(2):149-60

30. Vidal-Alaball J, Butler CC, Cannings-John R, et al. Oral vitamin B12 versus intramuscular vitamin B12 for vitamin B12 deficiency. Cochrane Database Syst Rev. 2005;(3):CD004655.

31. Devalia V, Hamilton MS, Molloy AM, British Committee for Standards in Haematology. Guidelines for the diagnosis and treatment of cobalamin and folate disorders. Br J Haematol. 2014;166(4):496-513.

\section{Publisher's Note}

Springer Nature remains neutral with regard to jurisdictional claims in published maps and institutional affiliations.

Ready to submit your research? Choose BMC and benefit from:

- fast, convenient online submission

- thorough peer review by experienced researchers in your field

- rapid publication on acceptance

- support for research data, including large and complex data types

- gold Open Access which fosters wider collaboration and increased citations

- maximum visibility for your research: over $100 \mathrm{M}$ website views per year

At $\mathrm{BMC}$, research is always in progress.

Learn more biomedcentral.com/submissions 